\title{
Variations in Production and Oligomers Content Obtained Under Hydrothermal Treatment Among Five Fast-Growing Species
}

\author{
M.J. Díaz ${ }^{*}{ }^{1}$, R. Yañez ${ }^{3}$, A. García Barneto ${ }^{1}$, J.E. Martín Alfonso ${ }^{1}$, M.J. Feria ${ }^{1}$, R. Tapias ${ }^{2}$ and \\ M. Fernández ${ }^{2}$
}

${ }^{I}$ Chemical Engineering Department, Facultad de Ciencias Experimentales, Campus El Carmen, Universidad de Huelva. 21071 Huelva Spain: ${ }^{2}$ Agroforestry Science Department, Escuela Politécnica Superior, Universidad de Huelva, La Rábida, Palos de la Frontera (Huelva), Spain; ${ }^{3}$ Chemical Engineering Department, Campus Ourense, Universidad de Vigo, Ourense Spain

\begin{abstract}
In order to identify fast growing species utilizable for olygomer and monomer production, five fast growing species (Paulownia fortunei, Chamaecytisus proliferus, Arundo donax, Leucaena.diversifolia and Sesbania grandiflora) were tested. Concurrently, the biomass productivity of these species was also tested on a field scale. The biomass productivity of the selected species studied ranges from 0.36 to $21.30 \mathrm{t} \mathrm{ha}^{-1}$ (o.d.b.) under Mediterranean conditions for the year 1 sprouts. In addition, the hydrothermal treatment results show that the selected species could be employed as alternative raw material for the production of oligomers, leading to a high concentration of oligomers $\left(9.4-23.4 \mathrm{~g} / \mathrm{L}^{-1}\right.$ at $\left.190^{\circ} \mathrm{C}\right)$.
\end{abstract}

Keywords: Paulownia fortunei, chamaecytisus proliferus, arundo donax, leucaena diversifolia, sesbania grandiflora, alternative pulp raw materials, hydrothermal treatment.

\section{INTRODUCTION}

There is a growing interest in the processes used to optimize lignocellulosic materials valorization. Because of this, the industry has an increased capacity to consume wood and non-wood chips, demanding not only forest wood stock, but also the prevision of the future industrial use of the wood that would be generated. The possible solutions involve a sustainable agricultural management that uses natural resources to enhance soil productivity without jeopardizing the land 's future potential. In this sense, the use of fast growing species could have a great advantage as these species provide remediation for the environmental problems associated with their industrial use- Moreover, the use of fast-growing species may offer some advantages in terms of soil restoration $[1,2]$ and the shorter time required to activate production in comparison with woody plants [3].

A possible efficient approach for lignocellulosic materials (LCM) processes is the "Biomass Refinery" philosophy [4]: the LCM is sequentially fractionated to obtain the main components (cellulose, hemicelluloses and lignin) in separated streams for an individualized profit of each. The first step in this fractionation can be autohydrolysis treatment, also known as hydrothermal treatment or hydrothermolysis. Autohydrolysis can solubilize oligomers almost quantitatively [5], dropping off the cellulose at solid phase and

*Address correspondence to this author at the Chemical Engineering Department. Facultad de Ciencias Experimentales. Campus El Carmen. Universidad de Huelva 21071 Huelva Spain Tel: +34 9592199 90;

Fax: +34 9592199 83; E-mail: dblanco@uhu.es inducing little modifications in the lignin. The autohydrolysis chemical fundament is the hydrolysis reactions of the hemicelluloses in aqueous medium, so these reactions are catalyzed by protons. In the initial stages of reaction, the protons come form the auto-ionization of water. The liquid resulting phase is composed principally of oligomer byproducts, xyloolygosaccharides (XO), monosaccharides, acetic acid, etc. The $\mathrm{XO}$ are the majority reaction products in the operation conditions usually gathered in the bibliography [6-8].

Moreover, the use of fast growing species for other uses, such as energy [9], alcohol production [10], pulp and papermaking [11], etc., has been extensively studied. However, few studies relate the production capacity of these species to their potential uses.

In this paper, we will evaluate different alternatives for the selected fast-growing species to quantify the variations of five different species a) on the yield obtained (total dry biomass and woody dry biomass), b) on the chemical composition changes of the raw material and c) on the chemical characteristics of the liquid obtained after an autohydrolysis treatment.

\section{EXPERIMENTAL}

\subsection{Experimental Design for Field Experiments}

Paulownia fortunei (Paulownia), Chamaecytisus proliferus (Tagasaste), Arundo donax (Arundo), Leucaena.diversifolia (Leucaena) and Sesbania grandiflora (Sesbania) were the species used in this work. The soil at the experimental site was sandy and loamy with a $\mathrm{pH}$ of 6-8, and having moderate to substantial depth. Field experiments 
were carried out in two plots, with a complete randomized block design with 4 replicates per species. In each block, 16 plants were planted in an area of $18 \mathrm{~m}^{2} ; 9500$ plants $^{-1}{ }^{-1}$ for Leucaena, Tagasaste and Sesbania; 2500 plants ha ${ }^{-1}$ for Paulownia and 21000 plants $\mathrm{ha}^{-1}$ for Arundo. These relations draw attention to the interrelationships between plant density (and thus the extent to which space is occupied), average plant size (and thus, arguably, levels of recent disturbance), and the crop frequency distribution [12]. No fertilizer was added to the plots for Leucaenas, Tagasaste and Sesbania. Several nitrogen fixing species can convert substantial quantities of atmospheric nitrogen into a combined form [13]. Therefore, it is not necessary to supply $\mathrm{N}$ to crops, although it would be advisable to apply $\mathrm{N}$ during the plantation stage. However, high soil $\mathrm{N}$ levels, particularly as nitrates, are known to inhibit nodulation and the nitrogen-fixing process [14]. For Paulownia and Arundo one inorganic fertilizer (150 g plant ${ }^{-1}$ ) was added.

Representative foliage and branch wood samples were collected (species-wise, quadruplicate) for moisture estimation and chemical analyses, in a random fashion. For yield estimation, four randomly selected plants per plot were cut at the base of the crown and immediately transferred to the laboratory in double-sealed polythene bags. After recording the fresh weights, they were dried to constant weights at $70^{\circ} \mathrm{C}$, and ground to pass through a $2 \mathrm{~mm}$ sieve. Estimates of dry weight biomass were obtained from the fresh weights of the various plant types and their corresponding moisture contents. Dry/wet ratios were used to correct the field weight determinations and to obtain biomass on a per plant basis. The average biomass of component parts per plant was multiplied by the number of plants per plot and extrapolated to a hectare.

\subsection{Characterization of the Raw Material}

Four samples representing the selected species were collected. Total and wood dry weights were measured. The harvesting of samples started in January; at that time the specimens had an age of 1 year.

Wood trimming samples were milled to pass through an $8 \mathrm{~mm}$ screen, since no diffusional limitations were observed for this particle size in preliminary studies. Samples were air-dried, homogenized in a single lot to avoid differences in composition among aliquots, and then stored. The wood trimmings were used including the bark, which was very thin and difficult to strip off, and accounted for only $1-2 \%$ of the overall mass.

Aliquots of raw material or solid residue obtained from the hydrothermal treatment were milled to a particle size < $0.5 \mathrm{~mm}$ and subjected to moisture and determination of extractable compounds (TAPPI T-264-om-88) and to Quantitative Acid Hydrolysis with $72 \% \mathrm{H}_{2} \mathrm{SO}_{4}$ following standard methods (T-249-em-85). The solid residue after hydrolysis was recovered by filtration and considered (corrected to its ash content) as Klason lignin. The monosaccharides (glucose, xylose and arabinose) and acetic acid contained in the hydrolysates were determined by HPLC, the features of which are mentioned below. Uronic acids were determined spectrophotometrically using galacturonic acid as a standard for quantification. Ashes were determined by calcination ( $\mathrm{T}$ 244-om-93). Compositions of raw material are shown in Table 1.

\subsection{Hydrothermal Processing of the Lignocellulosic Samples}

Raw material and water were mixed in the desired proportions and treated in a $600 \mathrm{~cm}^{3}$ stainless steel reactor (Parr Instruments Company, Moline, Illinois, USA) using a liquid/solid ratio (LSR) of $8 \mathrm{~kg}$ water $/ \mathrm{kg}$ raw material, on dry basis (the moisture content of material was considered as water). According to previous works, the influence of LSR is relatively low [5]. The reactor was fitted with four-blade turbine impellers, heated by an external fabric mantle and cooled by water circulating through an internal loop. The reaction media was stirred at $150 \mathrm{rpm}$ and heated to reach the desired temperature; time zero was considered to be the beginning of the isothermal stage. Fig. (1) shows the heating profile of the reactor.

After treatment, solid residues were recovered by filtration, washed with water, air-dried and weighed for yield determination. An aliquot of the liquors was oven- dried to constant weight to determine the dry content (DC, g non volatile compounds/g liquid phase). A second aliquot was filtered through $0.45 \mathrm{~mm}$ membranes and used for direct

Table 1. Chemical Composition ${ }^{\mathrm{a}}$ of the One Year Selected Fast-Growing Species

\begin{tabular}{|l|l|l|l|l|l|}
\hline & \multicolumn{1}{|c|}{$\begin{array}{c}\text { Holocellulose } \\
(\%)\end{array}$} & \multicolumn{1}{|c|}{$\begin{array}{c}\text { Klason } \\
\text { Lignin }(\%)\end{array}$} & \multicolumn{1}{|c|}{$\begin{array}{c}\text { Glucan } \\
(\%)\end{array}$} & \multicolumn{1}{|c|}{$\begin{array}{c}\text { Arabinan } \\
(\%)\end{array}$} \\
\hline \hline${ }^{\mathrm{b}}$ Paulownia. & $59.93(1.38)$ & $27.22(0.08)$ & $34.18(0.88)$ & $18.31(0.22)$ & $1.13(0.08)$ \\
\hline${ }^{\mathrm{c}}$ Tagasaste & $70.32(7.78)$ & $19.80(2.36)$ & $38.91(3.50)$ & $19.96(1.57)$ & $0.63(0.02)$ \\
\hline${ }^{\mathrm{d}}$ Arundo & $67.23(4.16)$ & $23.02(0.13)$ & $35.15(0.11)$ & $18.24(0.04)$ & $0.84(0.03)$ \\
\hline${ }^{\mathrm{e}}$ Leucaena & $77.91(2.50)$ & $19.02(2.51)$ & $40.11(2.40)$ & $15.71(1.62)$ & $3.39(0.84)$ \\
\hline${ }^{\mathrm{F}}$ Sesbania & $74.89(4.36)$ & $27.51(3.35)$ & $50.83(1.96)$ & $15.35(2.01)$ & $3.31(0.28)$ \\
\hline
\end{tabular}

${ }^{a}$ Percentages with respect to dray raw material (100 kg o.d.b.)

${ }^{b}$ Paulownia fortunei

${ }^{c}$ Chamaecytisus proliferus

${ }^{d}$ Arundo donax

${ }^{e}$ Leucaena.diversifolia

${ }^{f}$ Sesbania grandiflora

The values in brackets are standard deviation. 


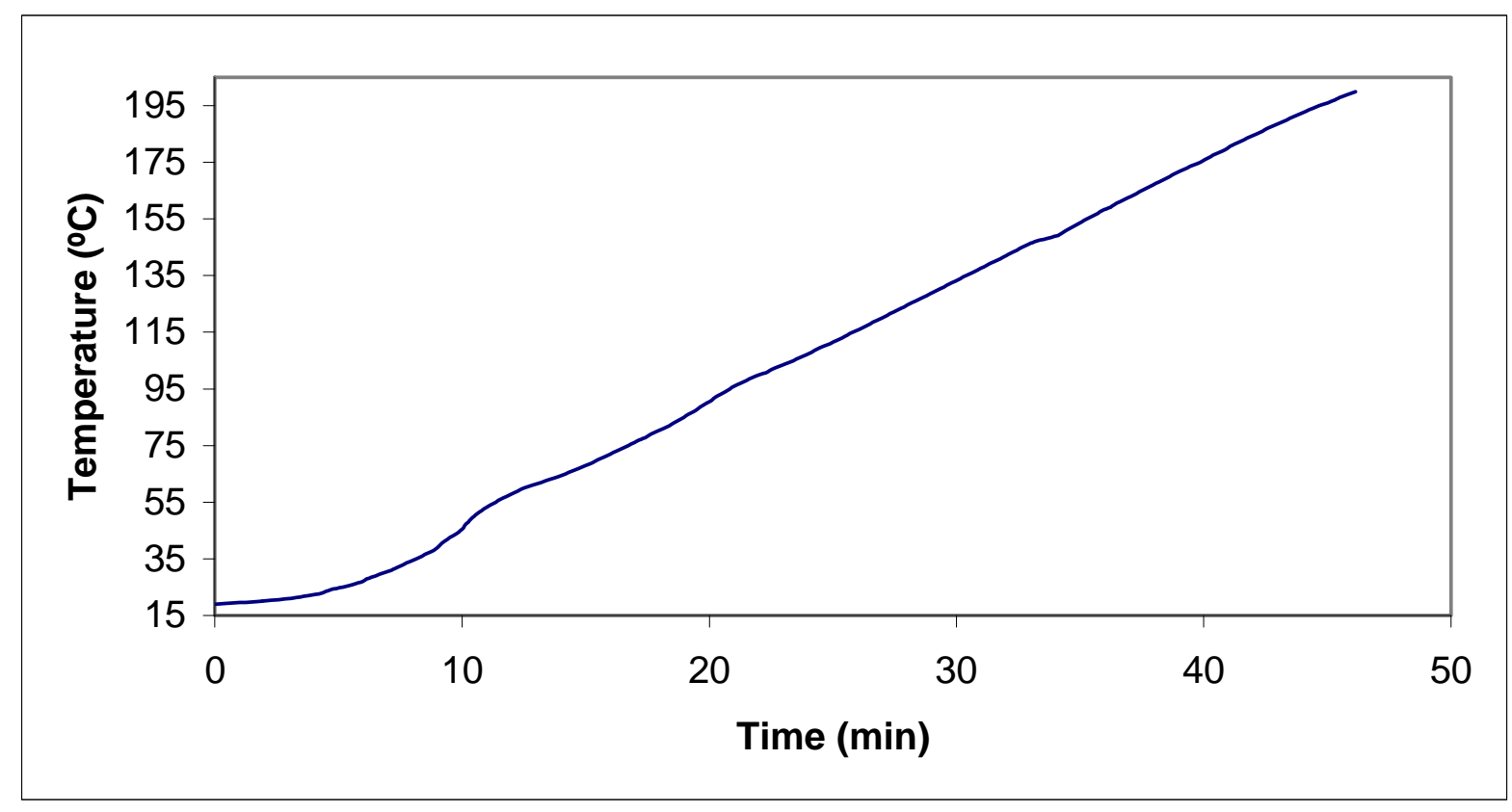

Fig. (1). Temperature profile in reactor during the heating process.

HPLC determination of monosaccharides, hydroxymethylfurfural (HMF) and acetic acid. A third aliquot was subjected to quantitative post-hydrolysis with $4 \% \mathrm{H}_{2} \mathrm{SO}_{4}$ at $121^{\circ} \mathrm{C}$ for $45 \mathrm{~min}$, before $0.45 \mathrm{~mm}$ membrane filtration and HPLC analysis. The increase in monosaccharide and acetic acid concentration caused by post-hydrolysis provided a measure of the olygomer concentration. HPLC analyses were performed using a BioRad Aminex HPX-87H column at $30^{\circ} \mathrm{C}$, eluted with $0.01 \mathrm{M} \mathrm{H}_{2} \mathrm{SO}_{4}$ at a flow rate of $0.6 \mathrm{~mL} \cdot \mathrm{min}^{-1}$, using a Refractive Index detector to quantify glucose, xylose, arabinose, acetic acid, HMF and furfural.

\section{RESULTS AND DISCUSSION}

\subsection{Chemical Characteristics of Raw Materials}

Table 1 displays the chemical characterizations for the first year of the varieties selected as raw materials. Moreover, Table 2 shows the chemical characterization of the other raw materials (hardwoods, softwoods and alternative raw materials).

In the studied species, the major fractions were cellulose and lignin, followed by hemicellulosic components.

In Table 1, higher values for Sesbania and lower values for Paulownia in holocellulose content with respect to other species are observed. The holocellulose contents found in the selected species are similar to those found for other similar raw materials (Table 2). Under the studied conditions, olygomer content is positively correlated with the holocellulose content, therefore a greater yield could be supposed for Leucaena (77.9\%), Sesbania (74.8\%) and Tagasaste (70.2\%).

As can be seen, Leucaena yielded a lower Klason lignin, similar to that found in Tagasaste. These values could suggest that these varieties may require low pulping of hydrothermal time and chemical charge compared to those of other raw materials. On the contrary, Sesbania and Paulownia lig- nin contents are higher than those found for other materials (Table 2).

The glucan content of Sesbania is higher than those found for the selected raw materials (Table 1). The rest of the selected materials show glucan values comparable to those obtained in the other materials. However, Sesbania and Leucaena show lower xylan values with respect to Paulownia, Tagasaste and Arundo. The $\alpha$-cellulose contents found in the studied species are in the range of the normal values expected for other raw materials and lower than those found for wood-based materials.

The quantity of xylan in the studied species shows similar values (15-20\%). The arabinan in Tagasaste shows lower values than those shown in the rest of the studied species. On the contrary, this species shows higher values in acetyl groups than the rest of the studied species.

The highest cellulose/oligomer ratio among the selected species was found for Sesbania (3.1). This ratio is very important due to the capital role that hemicelluloses play in papermaking [24]. Lower values were found for Paulownia (2.3), Tagasaste (2.2), Arundo (2.1) and Leucaena (2.1).

\subsection{Biomass Production}

All the species showed adequate soil and climatic adaptation to the zone (La Rábida, Huelva, southwestern Spain). Biomass accumulation for the studied species shows wide variations (Table $\mathbf{3}$ ).

Within the various species, significant differences in the yield obtained were observed. These results suggest a better initial development for seedlings in Arundo and Leucaena with respect to the others. The above ground biomass yield on a per hectare basis was significantly higher for Arundo, while Paulownia showed the lowest biomass production. Among the others, Leucaena yielded the highest total dry biomass $\left(7.45 \mathrm{t} \mathrm{ha}^{-1}\right)$. These differences were expected, due 
Table 2. Chemical Characterization of Some Raw Material

\begin{tabular}{|c|c|c|c|c|}
\hline Raw Material & $\begin{array}{c}\text { Holoce- } \\
\text { llulose (\%) }\end{array}$ & $\begin{array}{c}\text { Lignin } \\
(\%)\end{array}$ & $\alpha$-Cellulose (\%) & References \\
\hline \multicolumn{5}{|l|}{ Wood materials } \\
\hline Eucalyptus globulus & 80.5 & 19.9 & 52.8 & {$[15]$} \\
\hline Eucalyptus globulus & 79.5 & 21.2 & & {$[16]$} \\
\hline Pinus pinea & 69.6 & 26.2 & 55.9 & {$[15]$} \\
\hline \multicolumn{5}{|l|}{ Non-wood materials } \\
\hline Cannabis sativa $\mathrm{L}$. (hemp). & & 21.8 & 37.3 & {$[18]$} \\
\hline Cynara cardunculus $\mathrm{L}$. & 63.4 & 19.6 & 38.0 & {$[18]$} \\
\hline Panicum virgatum $\mathrm{L}$. (switchgrass) & 78.5 & 18.1 & & {$[21]$} \\
\hline Panicum virgatum L. (switchgrass) & 81.0 & 19.5 & & {$[22]$} \\
\hline Triticum sp. (wheat straw) & 70.7 & 21.7 & 41.3 & {$[22]$} \\
\hline Olea europaea (olive trimmings) & 69.1 & 17.6 & 41.0 & [23] \\
\hline
\end{tabular}

Table 3. Biomass Yielded in the First Year from Fast-Growing Species

\begin{tabular}{|c|c|c|}
\hline Species & $\begin{array}{c}\mathrm{WD}^{\mathrm{a}} \\
\left(\mathrm{t} \mathrm{ha}^{-1}\right) .\end{array}$ & $\begin{array}{c}\mathbf{T D}^{\mathrm{b}} \\
\left(\mathrm{t} \mathrm{ha} \mathbf{~}^{-1}\right)\end{array}$ \\
\hline Paulownia & $3.88(0.63)$ & $4.61(0.92)$ \\
\hline Tagasaste & $1.38(0.36)$ & $2.20(0.60)$ \\
\hline Arundo & $21.30(5.40)$ & $30.40(0.54)$ \\
\hline Leucaena & $4.83(0.17)$ & $7.45(0.96)$ \\
\hline Sesbania & $3.32(2.16)$ & $4.86(337)$ \\
\hline
\end{tabular}

The values in brackets are standard deviation.

${ }^{\mathrm{a}} \mathrm{WD}$ : Wood dry basis biomass $\left(\mathrm{t} \mathrm{ha}^{-1}\right)$.

${ }^{\mathrm{b}} \mathrm{TD}$ : Total dry basis biomass $\left(\mathrm{t} \mathrm{ha}^{-1}\right)$.

to the dissimilarities in plant density, average plant size and the crop frequency distribution.

The present study did not include any assessment of root characteristics; however, clear differences in the structure of the root systems among the species have been reported by Dimps et al., [25], Burleigh and Yamoah [26], Bell [27] and Dick et al. [28]. These authors reported that less radial symmetry in the root system is negatively correlated with initial growth.

Moreover, great differences between total dry biomass and wood dry biomass (branches and leaves wasted) among the species have been found. In this case also, the higher difference corresponds to Arundo ( $\left.9.1 \mathrm{t} \mathrm{ha}^{-1}\right)$. Furthermore, significant differences were found for Leucaena $\left(2.6 \mathrm{t} \mathrm{ha}^{-1}\right)$ and Sesbania $\left(1.5 \mathrm{t} \mathrm{ha}^{-1}\right)$. The smallest differences (most wood) have been found for Paulownia $\left(0.7 \mathrm{t} \mathrm{ha}^{-1}\right)$ and Tagasaste $\left(0.8 \mathrm{t} \mathrm{ha}^{-1}\right)$.

\subsection{Chemical Characteristics of Liquors from Hydro- thermal Treatment}

The operational conditions employed in this study (temperature (T) and reaction time (t)) are shown in Fig. (1). These processes are very influenced by temperature, caused by the rate of the involved reactions in the hydrothermal fractionation. The temperature was varied between 25 to $190^{\circ} \mathrm{C}$ and the subsequent reaction time. Under the selected conditions, little extent of hydrolytic reactions is found and the cellulose degradation is not important [5]. The exposed conditions were selected so that the experimental data obtained includes both the sugar generation and the oligomer decomposition [29-31].

Table 4 shows the values found for the chemical characterization of the liquid product from the hydrothermal treatment. 
Table 4. Product Distribution ${ }^{a}$ of the Fast-Growing Species Under $\left(190^{\circ} \mathrm{C}, 1 / 8 \mathrm{Solid} /\right.$ Liquid Ratio $)$ Non-Isothermal Autohydrolysis Treatment ${ }^{b}$

\begin{tabular}{|c|c|c|c|c|c|c|}
\hline & $\begin{array}{l}\text { Oligomers } \\
\text { (g/L) }\end{array}$ & $\begin{array}{c}\text { Glucose } \\
\text { (g/L) }\end{array}$ & $\begin{array}{c}\text { Xylose } \\
\text { (g/L) }\end{array}$ & $\begin{array}{l}\text { Arabinose } \\
\qquad(\mathrm{g} / \mathrm{L})\end{array}$ & Acetic acid (g/L) & $\begin{array}{c}\mathbf{H M F}^{\mathbf{b}} \\
(\mathrm{g} / \mathbf{L})\end{array}$ \\
\hline Paulownia & $9.45(0.31)$ & $0.72(0.10)$ & $1.13(0.13)$ & $0.41(0.07)$ & $0.52(0.10)$ & $0.11(0.01)$ \\
\hline Tagasaste & $23.48(1.94)$ & $2.13(0.42)$ & $2.81(0.31)$ & $1.02(0.22)$ & $1.92(0.21)$ & $0.13(0.02)$ \\
\hline Arundo & $17.24(1.00)$ & $0.81(0.09)$ & $0.64(0.17)$ & $0.21(0.03)$ & $1.33(0.18)$ & $0.12(0.01)$ \\
\hline Leucaena. & $18.72(1.13)$ & $2.43(0.31)$ & $0.82(0.16)$ & $0.41(0.13)$ & $0.93(0.11)$ & $0.11(0.03)$ \\
\hline Sesbania & $14.17(1.26)$ & $3.26(0.63)$ & $12.20(0.90)$ & $0.43(0.16)$ & $2.35(0.37)$ & $0.12(0.02)$ \\
\hline
\end{tabular}

${ }^{\mathrm{a}}$ Percentages with respect to dray raw material (100 kg o.d.b.).

${ }^{\mathrm{b}}$ The values in brackets are standard deviation.

The behavior of the lignin fraction of wood can be assessed by the proportion of lignin remaining in the solid phase after the selected treatment (98\%). Consequently, delignification was seen not to be an important effect of hydrothermal treatments.

The oligomers in the liquor obtained for Tagasaste and Sesbania reach higher values with respect to other varieties. This value represents $74.7 \%$ and $58.9 \%$ of the total of oligomers initially present in the raw material respectively. The high olygomer values obtained could be related to the high acetyl groups content in the raw material value. Under autohydrolysis treatment, the role of formation of hydronium ions, which catalyzes the oligomers depolymerization, from acetic acid is more important than for water autoionization. It is because the dissociation constant of acetic acid is higher than that of water [32]. In that form, the water autoionization role is limited to the initial reaction stages. The lowest value has been found for Leucaena $(53.7 \%)$. Medium values have been found for Paulownia (36.7\%), Arundo (53.7\%) and Sesbania $(58.8 \%)$. It is possible to emphasize that the Tagasaste reaches the highest value both in total oligomers and the maximum percentage extracted.

In the above-mentioned table, low glucose values among the species have been observed. This data is in agreement with the little cellulose degradation that occurs in treatments at temperatures below $230^{\circ} \mathrm{C}$ [7]. However, a different behaviour, characterized by an increased susceptibility towards cellulose hydrolysis, has been determined for Sesbania, Leucaena and Tagasaste with respect to Arundo and Paulownia.

Among the oligomers (with the exception of glucose) xylose reaches higher concentrations; this is because the majority of the hemicellulosic fraction of the agricultural materials is xylan, a structure formed by xylose monomers with different ramification such as arabionse, acetyl groups or uronic acids [33]. In this form, the highest value has been found for Sesbania and few significant differences have been found for the rest of species.

In general, for the others parameters measured (arabinose and acetic acid), a similar relation to that obtained for xylose has been observed. This general trend has been previously described by Yañez et al., [34]. An exception could be made for Arabinose in Arundo, and lower concentrations than expected for this material have been found.
Furfural and hydroxymethyl furfural are sugar-dehydration products, therefore, the concentration of both products will increase in direct proportion to an increase in time and temperature.

Under these conditions, neither significant values (furfural) nor differences have been found for 5-hydromethyl furfural contents in the selected species.

\section{CONCLUSIONS}

The chemical characteristics of studied species (Paulownia fortunei, Chamaecytisus proliferus, Arundo donax, Leucaena.diversifolia and Sesbania grandiflora, report positively on its possible use as alternative source of oligomers.

Significant differences, both in total and wood dry biomass yield obtained, were observed within the different species. Arundo donax has obtained the highest value among all the evaluated varieties (30.4 $\mathrm{t} \mathrm{ha}^{-1}$ in total dry biomass). On the contrary, the lowest total dry biomass has been found for Paulownia fortunei.

The study confirms the feasibility of the non-isothermal autohydrolysis treatment process for the selected species to yield sugar oligomers and hemicellulosic sugar, and low degradation product concentrations have been found.

Under this process, large amounts of oligomers in the liquor (with respect to initial raw material content) could be obtained for Paulownia fortune (36.7\%), Chamaecytisus proliferus $(74.7 \%)$, Arundo donax (53.7\%), Leucaena.diversifolia (49.5\%) and Sesbania grandiflora (58.9\%).

\section{ACKNOWLEDGEMENTS}

The authors acknowledge financial support from the CICYT (Science and Technology Inter Ministerial Commission, Spanish Government)-FEDER, project number CTM2007-62117/TECNO.

\section{REFERENCES}

[1] Vanlauwe B, Sanginga N, Merckx, R. Recovery of Leucaena and Dactyladenia residue $15 \mathrm{~N}$ in alley cropping systems. Soil Sci Am J 1998; 62: 454-60.

[2] Gullón P, Moura P, Esteves MP, Girio FM, Dominguez H, Parajó, JC. Assessment on the fermentability of xylooligosaccharides from rice husks by probiotic bacteria. J Agric Food Chem 2008; 56: 7482-87. 
[3] Oggiano N, Angelini LG, Cappelletto P. Pulping and paper properties of some fibre crops. Ind Crops Prod 1997; 7 (1): 59-67.

[4] Myerly RC, Nicholson MD, Katzen R, Taylor JM. The forestry refinery. Chemtech 1981; 11: 186-92.

[5] Garrote G, Domínguez H, Parajó JC. Hydrothermal processing of lignocellulosic materials. Holz Roh Werks 1999; 57: 191-202.

[6] Kabel MA, Carvalheiro F, Garrote G, et al. Hydrothermally treated xylan rich by-products yield different classes of xylo-oligosaccharides. Carbohyd Polym 2002; 50: 47-56.

[7] Garrote G, Eugenio ME, Díaz MJ, Ariza J, López F. Hydrothermal and pulp processing of Eucalyptus. Biores Technol 2003; 88: 6168.

[8] Liu C, Wyman CE. Partial flow of compressed-hot water through corn stover to enhance hemicellulose sugar recovery and enzymatic digestibility of cellulose. Biores Technol 2005; 96: 1978-85.

[9] Yaman S. Pyrolysis of biomass to produce fuels and chemical feedstocks. Energ Convers Manag 2004; 45: 651-71.

[10] Bridgeman TG, Darvell LI, Jones JM, et al. Influence of particle size on the analytical and chemical properties of two energy crops. Fuel 2007; 86 (1-2): 60-72.

[11] Caparrós S, Ariza J, Garrote G, López F, Díaz MJ. Optimization of Paulownia Fortunei L. Autohydrolysis-Organosolv pulping as a source of xylooligomers and cellulose pulp. Ind Eng Chem Res 2007; 46: 623-31

[12] Niklas KJ, Midgley JJ, Richard H. RandTree size frequency distributions plant density age and community disturbance. Ecol Lett 2003; 6: 405-11.

[13] Kumar BM, Kumar SS, Fisher RF. Intercropping teak with Leucaena increases tree growth and modifies soil characteristics. Agrofor Sys 1998; 42: 81-89.

[14] Duhoux E, Dommergues Y. In: Ssali H, Keya SO, Eds. Biological Nitrogen Fixation in Africa. The use of nitrogen fixing trees in forestry and soil restoration in the tropics. Kenya MIRCEN-University of Nairobi 1985; pp. 384-400.

[15] Alonso L. Análisis químico de maderas de diferentes especies forestales. INIA Ed. Madrid, Spain: Ministerio de Agricultura 1976; p. 368.

[16] Gilarranz MA, Rodríguez F, Santos A, Oliet M, Garcia-Ochoa F, Tijero J. Kinetics of Eucalyptus globulus delignification in a methanol-water medium. Ind Eng Chem Res 1999; 38 (9): 3324-

[17] Parajó JC, Vázquez D, Alonso JL, Santos V. Optimization of catalysed acetosolv fractionation of pine wood. Holzforschung 1993; 47: 188-96.

[18] Antunes A, Amaral E, Belgacem MN. Cynara cardunculus L chemical composition and soda-anthraquinone cooking. Ind Crops Prod 2000; 12 (2): 85-91.
[19] Jiménez L, López F, Ferrer JL, Herranz JL. Evaluation of agricultural residues for paper manufacture. Tappi J 1993; 76 (3): 169-73.

[20] Khristova P, Kordsachia O, Patt R, Khider T, Karrar I. Alkaline pulping with additives of kenaf from Sudan. Ind Crops Prod 2002; 15 (3): 229-35.

[21] Law KN, Kokta BV, Mao CB. Fibre morphology and soda-sulphite pulping of switchgrass. Biores Technol 2001; 77 (1): 1-7.

[22] Sun RC, Tomkinson J. Separation and characterization of cellulose from wheat straw. Sci Technol 2004; 39 (2): 391-411.

[23] Díaz MJ, Eugenio ME, Lopez F, Alaejos J. Paper from olive tree residues. Ind Crops Prod 2005; 21 (2): 211-21.

[24] Cordeiro N, Belgacem MN, Torres IC, Moura JCVP. Chemical composition and pulping of banana pseudo-stems. Ind Crops Prod 2004; 19 (2): 147-54.

[25] Dimps RC, Goh CJ, Kumar PP. High frequency plant regeneration from excised leaves of Paulownia fortune. Vitro Cell Dev Biol Plant 1993; 29 (2): 72-76.

[26] Burleigh JR, Yamoah CF. Site factors associated with the performance of Leucaena leucocephala (Lam.) de Wit and Sesbania sesban $(L$.$) Merill in pure and mixed stands in the northern highlands of$ Rwanda. Agrofor Sys 1997; 37: 121-31.

[27] Bell G. In: Brock JH, Wade M, Pysek P, Green D, Eds. Plant Invasions: Studies from North America and Europe. Ecology and management of Arundo donax and approaches to riparian habitat restoration in Southern California. The Netherlands Blackhuys Publishers Leiden 1997; pp. 103-13.

[28] Dick J, Magingo F, Smith RI, McBeath C. Rooting ability of Leucaena leucocephala stem cuttings. Agrofor Sys 1999; 42: 149-57.

[29] Palmarola-Adrados B, Galbe M, Zacchi G. Pretreatment of barley husk for bioethanol production. J Chem Technol Biotechnol 2005; 80: 85-91.

[30] Parajó JC, Garrote G, Cruz JM, Domínguez H. Production of xylooligosaccharides by autohydrolysis of lignocellulosic materials. Trends Food Sci Tecnol 2004; 15: 115-20.

[31] Caparrós S. Díaz MJ, Ariza J, López F, Jiménez L. New perspectives for Paulownia fortunei $L$. valorization of the autohydrolysis and pulping processes. Biores Technol 2008; 99: 741-49.

[32] Carrasco F. Fundamentos del fraccionamiento de la biomasa Afinidad 1989; 46: 425-29.

[33] Ebringerova A, Heinze T. Xylan and xylan derivativesbiopolymers with valuable properties. 1. Natural occurring xylan structures isolation procedures and properties. Macromol Rapid Commun 2000; 21: 542-56.

[34] Yáñez R, Garrote G, Díaz MJ. Valorisation of a leguminous specie, Sesbania grandiflora, by means of hydrothermal fractionation. Biores Technol 2009; 100 (24): 6514-23.

This is an open access article licensed under the terms of the Creative Commons Attribution Non-Commercial License (http://creativecommons.org/licenses/ by-nc/3.0/) which permits unrestricted, non-commercial use, distribution and reproduction in any medium, provided the work is properly cited. 